\title{
Avaliação dos marcadores celulares por citometria de fluxo em pacientes com leucemia mieloide aguda
}

\author{
Evaluation of cellular markers by flow cytometry in patients with acute myeloid leukemia
}

\author{
Roberto C. Vasconcelos \\ Orientador: Geraldo B. Cavalcanti Júnior
}

\section{Resumo}

A leucemia mieloide aguda (LMA) é uma neoplasia do tecido hematopoético que se caracteriza pela proliferação anormal de células progenitoras da linhagem mieloide, refletindo em alterações no sangue periférico, tais como anemia e trombocitopenia, e leucocitoses às custas de células mieloides imaturas. Com o advento da imunofenotipagem com anticorpos monoclonais (AcMo) através da citometria de fluxo (CF), o diagnóstico dessas leucemias se tornou mais preciso. O objetivo deste trabalho foi diagnosticar casos de LMAs com base na imunofenotipagem e classificação morfológica pelos critérios do grupo Franco Americano e Britânico (FAB), por CF, com um painel de AcMo em amostras de aspirado de medula óssea de 179 portadores de LMA encaminhadas ao Hemocentro do Rio Grande do Norte - Hemonorte, procurando estabelecer padrões de expressão antigênica para os diversos subtipos FAB dessas leucemias e também observar a frequência de casos com fenótipos aberrantes além de dados clínicos. Dos portadores de LMAs investigadas, $92(51,4 \%)$ eram do sexo feminino e $87(48,6 \%)$ do sexo masculino, com faixa etária variando de 3 a 95 anos de idade, com maior incidência na faixa etária de 41 a 65 anos. Observou-se correlação entre a imunofenotipagem e classificação $\mathrm{FAB}$, com os seguintes resultados: dois casos (1,1\%) LMA-M0, 40 (22,3\%) LMA-M1, 60 (33,5\%) LMA-M2, 22 (12,3\%) LMA-M3, 10 (5,6\%) LMAM4, 13 (7,3\%) LMA-M5, 06 (3,4\%) LMA-M6 e um caso $(0,6 \%)$ de LMA-M7. Com relação à presença de fenótipos aberrantes, observou-se predomínio do antígeno $\mathrm{CD} 7$ presente em trinta casos $(16,8 \%)$, notadamente nos casos de LMA-M1 e M2, seguido pelo CD4 mais observado nos casos de LMA-M4 e M5. Outros marcadores linfoides mostraram-se presentes, embora com menor frequência, tais como o TdT em 3,9\%, CD3 em 2,8\% e o CD19 em
$1,9 \%$ dos casos. A esplenomegalia foi o achado clínico mais presente, perfazendo um total de 147 casos $(82,1 \%)$, seguida pela hepatomegalia com 132 casos $(73,7 \%)$. Fenômenos hemorrágicos e trombocitopenia foram observados em 55 casos $(30,7 \%)$ estando mais presentes nas leucemias promielocíticas. Estes dados demonstram a importância da imunofenotipagem no diagnóstico das LMAs, visando um tratamento adequado e um melhor acompanhamento dos portadores destas leucemias.

Palavras-chave: Leucemia mieloide aguda; citometria de fluxo; imunofenotipagem.

\section{Abstract}

Acute myeloid leukemia (AML) is a neoplasm of hematopoietic tissue characterized by abnormal proliferation of myeloid lineage progenitor cells, reflecting in changes in the peripheral blood including anemia, thrombocytopenia and leukocytosis at the cost of immature myeloid cells. With the advent of immunophenotyping by flow cytometry (FC) employing monoclonal antibodies (MoAb), the diagnosis of these leukemias has become more accurate. The aim of this study was to diagnose cases of AML based on immunophenotyping and morphological classification using the criteria of the French-American-British group (FAB) employing a MoAb panel in samples of bone marrow aspirate from 179 AML patients, in order to establish patterns of antigen expression for the different FAB subtypes. Additionally, the frequencies of cases with aberrant phenotypes were evaluated as were the clinical criteria. All patients were referred to the Hemocentro do Rio Grande do Norte-Hemonorte. Of the AML patients studied,

Dissertação de mestrado apresentada ao programa de Pós-Graduação em Ciências Farmacêuticas (PPgCFAR) da Universidade Federal do Rio Grande do Norte (UFRN).

Universidade Federal do Rio Grande do Norte (UFRN), Centro de Ciências da Saúde (CCS), Programa de Pós-Graduação em Ciências Farmacêuticas - PPgCFAR - Natal-RN.

Correspondência: Geraldo Barroso Cavalcanti Junior

Disciplina de Imunologia Clínica - Departamento de Análises Clínicas e Toxicológicas -DACT/CCS/UFRN

Faculdade de Farmácia

Rua General Gustavo Cordeiro de Farias s/n-Petrópolis

59010-180 - Natal-RN - Brasil

E-mail: gbcjunior@hotmail.com 
$92(51.4 \%)$ were female and 87 (48.6\%) were male, with ages ranging from 3 to 95 years old; a higher incidence was seen in the 41 to 65 age group. A correlation was identified between immunophenotype and FAB classification, with the following results: two cases $(1.1 \%)$ AML-M0, 40 (22.3\%) AML-M1, 60 (33.5\%) AML-M2, 22 (12.3\%) AML-M3, 10 (5.6\%) AML-M4, 13 (7.3\%) AML-M5, 6 (3.4\%) AML-M6 and one case (0.6\%) of AML-M7. In respect to the presence of aberrant phenotypes, the antigen CD7 was the most prevalent identified in 30 cases (16.8\%), especially in AMLM1 and M2, followed by CD4 observed in most cases of AMLM4 and M5. Other lymphoid markers were present although less frequently, such as TdT in $3.9 \%$ of cases, CD3 in $2.8 \%$ and CD19 in $1.9 \%$. Splenomegaly was the commonest clinical finding in 147 cases $(82.1 \%)$, followed by hepatomegaly in 132 cases $(73.7 \%)$. Hemorrhagic phenomena and thrombocytopenia were observed in 55 cases $(30.7 \%)$ more commonly in promyelocytic leukemia. These data demonstrate the importance of immunophenotyping in the diagnosis of AML, in order to provide the appropriate treatment and better monitoring of patients with these leukemias.

Key words: Acute myeloid leukemia; flow cytometry; immunophenotyping.

Suporte Financeiro: Fundação de apoio a Pesquisa do Estado do Rio Grande do Norte - Fapern; Coordenação de Aperfeiçoamento de Pessoal de Nível Superior - Capes; Pro-Reitoria de Pesquisa da Universidade Federal do Rio Grande do Norte.

Avaliação: A Revista Brasileira de Hematologia e Hemoterapia (RBHH) publica os resumos e abstracts de teses da área apresentados em entidades que tenham programas de pós-graduação reconhecidos pelo MEC/Capes e considera a obtenção do título suficiente para sua publicação na forma como se propõe a seção.

Recebido: $28 / 02 / 2010$

Aceito: 01/03/2010 